\title{
IMPACT OF BUSINESS EDUCATION ON CORPORATE SOCIAL RESPONSIBILITY (CSR)
}

\author{
Rana Jimshaid Asghar1 \\ Research Coordinator at Pakistan Institute for Parliamentary Services \\ (PIPS) \\ Anbreen Jimshaid 2 \\ Research Scholar \\ Ali Iftikhar Choudhary 3 \\ Lecturer, COMSATS Institute of Information Technology, Vehari \\ Dr. Asad Afzal Humayon 4 \\ HOD MS Deptt, COMSATS Institute Of Information Technology, Veahri
}

\begin{abstract}
Objective:- Corporate social responsibility is basically focused by the organizations for the better environment of the organization. Current study has discussed some variables which have direct and indirect impact on CSR, Such as Business education, Manager Profile, subordinate of ethics and social responsibility. This research explored the impact of Business education on CSR. Methodology:- Education sector was selected for the analysis and is quantitative approach. The sampling technique was simple random sampling with the sample of 300 employees. Standardized questionnaire was used for the data collection. The results were analyzed by using Multiple Regressions on AMOS. Findings:- Reliability of the variables are shown as, Manager Profile was (69\%), Business Education (80.7\%), Subordinate of ethics and social responsibility reliability $(83.8 \%)$. Findings show positive impact of manager's profile and business education on CSR. Practical Implications:- As managers are the leaders of the organization and the whole organizational environment based on managerial performances. If management is active and efficient ethically and socially towards the employees and the organizational goals it's obvious that organizational performance will be positive.
\end{abstract}

Keywords : Corporate social Responsibility, Business Education, Pakistan

\section{Jel Classification: D920, E220, F210}

\footnotetext{
* The material presented by the author does not necessarily portray the viewpoint of the editors and the management of the Institute of Business \& Technology (IBT)

Rana Jimshaid Asghar Anbreen Jimshaid

Ali Iftikhar Choudhary

Dr. Asad Afzal Humayon

jimshaidasghar@gmail.com

anbreenjimshaid2013@gmail.com

ali@ciitvehari.edu.pk

asadhumayon@ciitvehari.edu.pk

C IBTJBS is published by the Institute of Business and Technology (IBT).

Main Ibrahim Hydri Road, Korangi Creek, Karachi-75190, Pakistan.
} 


\section{INTRODUCTION}

Corporate social responsibility (CSR) is previously discussed by the various studies which show different impact. Relation of Manager Profile is also discussed which has direct link with CSR and Subordinate of ethics \& social responsibility. As managers are the leaders of the organization and the whole organizational environment based on managerial performances. If management is active and efficient, ethically and socially towards the employees and the organizational goals then it's obvious that organizational performance will be positive. It is the management who look after the corporate social responsibility. The top manager only shows positive actions in ethics and social responsibility in corporate (Waldman et al., 2006).

Previous article focuses on this question by analysing how a manager's profile is linked to the development of CSR practices, as well as the mediating effect of their perception of the role of ethics and social responsibility (Campillo et. al. 2011). Jensen and Meckling (1976) describes that agency theory declares that managers as an agents are individual who gain their own satisfaction even at the expense of firms so it is clear that agent is opportunist. Davis et al., (1997) gave the steward theory; the main purpose of this theory is to understand the manager profile. Sethi, 1979 discuss in his articles three major dimension social obligation, social responsiveness and social responsibility. Basically in his research he clears that how organization face the social pressure and how they perform business activities. Jensen, 2002 describes that if in the organization manager's act in a socially and ethically responsible way then the stakeholder relationship with the organization will be improved, because of healthy relationship cost will be low and overall efficiency of the organization will be increased.

Scope of this research is to elaborate the significance of Business education and Manager Profile on CSR and subordinate of ethics and social responsibility. Business education plays vital role in the current research by having direct link with the CSR and Subordinates of ethics and social responsibility. It give boost to the ethics in organization and corporate society. Indeed, it is the top manager's responsibility to spread interest in ethics and social responsibility in the firm (Waldman et al., 2006) and shows how to integrate these through a process of strategic management (Singhapakdi et al., 2008)

Objective of this study is to make the CSR stronger in order to polish it with the help of Business Education, Manager Profile and subordinates of ethics and social responsibility which will be proven an achievable reward for the organization as well as for the corporate sector. This research thus extends the knowledge and idea of how CSR is improved by the support of manager profile and Business Education. Caldwell et al., in 2008 defines that steward's managers primary concern is to maximize the organizational long term value and built the relationship with the stakeholders. Main contribution in this study is the "Business Education", this is the new variable which has not previously discussed in past studies of CSR, though by addition of this variable the CSR will be further improved and will have positive consequences in near future. 


\section{Literature Review and Hypothesis Development}

\subsection{Manager's Profile: Steward Approach}

According to Davis et al., (1997) psychological factors considered to be manager's personal characteristics. Characteristics may have impact on work of managers, how they work in the organization? What is the manager's motivation and how they use their power in the organization. The psychological factors basically provide the detail information how each factors affect the managers. Wasserman in $2006 \&$ Chrisman et al. in 2007, describes that the agency steward approach declared that managers profile as an agent, they also described the steward in terms of psychological and situational factors. Hernandez, (2008) describes that the main aim of this theory is to satisfy the stakeholder and maximize the firm's value. Thus it is clear that each managerial profile has different behavior, and perception of managers, according to this they make the decision in the organization.

\section{Manager Profile $\longrightarrow$ Ethics and Social Responsibility}

Porter and Kramer, 2006 declares that if in an organization effectively manage the relationship with the stakeholder then the competitive advantage of the organization will be increased. Caldwell et al., 2006 describes in his study that social responsibility is not only related with the shareholder and stakeholder, manager should also have positive attitude toward the social responsibilities and corporate social responsibilities (CSR). Barnett, 2007; Bhattacharya et al., 2008 describes that because of social responsibility, corporate social responsibility (CSR) distinguished from the other corporate investment. In his article he declares that the modern theory of corporate social responsibility (CSR) is to act in a socially responsible way, this thing improves the relationship of the stakeholder and shareholders. Caldwell et al., 2008 defines that according to steward's managers primary concern is maximize the organizational long term value and built the relationship with the stakeholders. Thus it is clear that for the organization effectiveness it is necessary to act in a socially responsible way. Hence on the base of literature it is stated that

\section{H1: Manager Profile Has Positive Impact on Ethics and Social Responsibility}

\section{MANAGER PROFILE $\longrightarrow$ CORPORATE SOCIAL RESPONSIBILITY}

Managers should have the capability to follow the corporate social responsibility (CSR) in their organization. Managers have the authority to act in social responsible way (Donaldson 1990; Hambrick and Finkelstein, 1987). Mostly decisions in organizations have been taken by the top managers, in such case top management should have to take such decision which are beneficial for overall organization .Organization's top management should have to follow the corporate social responsibility (CSR) practices (Thomas \& simerly, 1994). Hambrick, 2007 describes that managers should have the ability to realize the direction, how to act in socially responsible way in the organization. Hernandez, 2008 described that steward theory basically give the manager's authority and guide line to create trust and motivation in the organization. Hence on the base of literature it is hypotheses that. 


\section{H2: Manager Profile Has Positive Impact on Corporate Social Responsibility (CSR) \\ Manager Profile $\longrightarrow$ Ethics And Social Responsibility $\longrightarrow$ CSR}

Manager profile is a conditional behavior, but their relation is not direct with the corporate social responsibility (Fishbein \& Ajzen, 1975). Marta et al., 2004 describes that ethics and social responsibility have influence on the managers. Manager's behavior reflects more corporate responsible if ethics and social responsibility is part of their organizational goals, then managers act more responsible towards their organization (Kassinis and Panayiotou, 2006). Managers should act socially responsible in a way that the manager will be able to perform the corporate social responsibility (CSR) practices in their organization (Singhapakdi et al., 2008). Thus on the base of literature it is professed that ethics and social responsibility mediates the relationship between corporate social responsibility (CSR) and manager profile.

\section{H3: Ethics and Social Responsible Mediates: The Relationship between the Manager Profile and Corporate Social Responsibility (CSR)}

\section{Business Education $\longrightarrow$ Corporate Social Responsibility}

The concept of corporate social responsibility (CSR) has been explored a number of time. Joyner \& Payne in (2002) described that business education is precisely essential now a days, according to them because of business education we know about the market value, price and production. They also acknowledged that business affianced in ethical business practices. Here the researcher visualized the link between the business ethics and corporate social responsibility (CSR).In corporate social responsibility (CSR) they acquired the economic responsibility, legal responsibility, ethical responsibility and discretionary responsibility thus the study declared that business ethics and corporate social responsibility (CSR) have direct and indirect relationship, because when people have knowledge about the business ethics then they will be socially responsible (Panapanaan et al,. 2003). In past a lot of work have been done on the corporate social responsibility (CSR) and was focused on economic and environmental dimension but not much work have been done over the business issues. Business education is compulsory for the corporate social responsibility (CSR), here researcher discussed that management area of corporate social responsibility that are employees, community, customers and suppliers.

Matten \& Moon (2004) describes in their paper about corporate social responsibility (CSR) education in business school. In this study they basically find out what is the importance of corporate social responsibility and how can we teach corporate social responsibility (CSR). In this paper they basically raise the question what is the role played by the business education in terms of corporate social responsibility (CSR).Thus the study acknowledged that there is strong orientation of corporate social responsibility (CSR) to business relevance. Angelidis \& Ibrahim in (2004) stated that researcher have done a lot of work on corporate social responsibility (CSR) but in this study they focused on how business education and religion have impact on corporate social responsibility(CSR) here they take the corporate social responsibility (CSR) in term of economic. Legal, ethical and discretionary, according to them in institution business education student must know about corporate social responsibility (CSR). Thus the 
responsibility because employees don't know what is corporate social responsibility (CSR) thus it is stated that in institution it is necessary to provide the information regarding corporate social responsibility (CSR).

Sleeper et al, (2006) defines in his article the importance of business education towards the social responsibility. According to them business education is very important for the students and mostly business institution focus on corporate social responsibility (CSR).In business education students get the information how to perform social responsibility. In their study they declared that business education and corporate social responsibility have a relationship because the research shows that the student who has business education they can effectively perform the social responsibility thus there is positive relationship between corporate social responsibility (CSR) and business education. Christensen et al, (2007) in this paper examine how the business education addresses the corporate social responsibility (CSR).They basically observed that in institutions what subject offer in business education either they cover the ethics, corporate social responsibility (CSR) or sustainability . The research was conducted from the institutions and after the analysis it is stated that business studies have a link with the ethics, corporate social responsibility (CSR) and sustainability. Thus on the base of extensive literature it is purposed that.

\section{H4: Business Education Has Positive Impact on Corporate Social Responsibility (CSR)}

\section{Business Education $\longrightarrow$ Ethics,Social Responsibility $\longrightarrow$ CSR}

According to the literature social ethical responsibility mediates the relationship between the corporate social responsibility (CSR) and business education. Wimbush, Shepard and Markham, 1997 describes in their studies that education have a link with the ethical social responsibility. It is expected that education has a positive effect on ethical climate and ethical behavior, and therefore should be controlled. Training is an important activity for the ethical social responsibility. In this article they take the corporate social responsibility as economic, ethical and legal responsibility (Edmondson \& Carroll, 1999). Through the business education employees have knowledge about their ethics and responsibility. When all the employees are responsible then they will follow the corporate social responsibility (CSR) practices (Matten \& Moon, 2004). Social, ethical responsibility misdates the relationship between the business education and corporate social responsibility (Sleeper et al, 2006). Hence on the base of pervious study it is stated that

H5: Social Ethical Responsibility Mediates The Relationship between the Corporate Social Responsibility (CSR) and Business Education.

\section{Therotical Framework}

Appendix A: See Figure 1.1 


\section{RESEARCH METHODOLOGY}

\subsection{Manager Profile}

Manager's profile is an independent variable, agency steward approach declared that managers profile as an agent, they also described the steward in terms of psychological and situational factors (Wasserman, 2006; Chrisman et al., 2007). Porter and Kramer, 2006 declares that if in an organization effectively manage the relationship with the stakeholder then the competitive advantage of the organization will be increased. In this research paper we measure manager's profile on five point likert scale through questionnaire factors given by (Davis et al., 1997).

\subsection{Business Education}

Business education is also independent variable, Joyner \& Payne in (2002) described that business education is precisely essential now a days, because of business education we know about the market value, price and production. They also acknowledged that business affianced in ethical business practices. Here the researcher visualized the link between the business ethics and corporate social responsibility (CSR), for the business education questionnaire is taken from (Sleeper.j et al., 2006) and will be measured on five point likert scale.

\subsection{Ethical Social Responsibility}

In this research paper ethical social responsibility is used as a media0ting variable. Marta et al., 2004 describes that ethics and social responsibility have influence on the managers. Kassinis and Panayiotou, 2006 describes that manager behavior reflect more corporate responsible if ethics and social responsibility is part of their organization goals. In this paper, measure the ethical social responsibility through the questionnaire that is given by Fornell and Larcker, 1981, Etheredge, 1999; Singhapakdi et al., 2008; Yaman and Gurel, 2006.

\subsection{Corporate Social Responsibility (CSR)}

Corporate social responsibility (CSR) is dependent variable. Hambrick and Finkelstein, 1987 describes that managers should have the capability to follow the corporate social responsibility (CSR) in their organization. Managers have the authority to act in social responsible way (Donaldson 1990). In this research paper we measure the corporate social responsibility (CSR) practices through the questionnaire given by Prado-Lorenzo et al. 2008.

\subsection{Sampling Technique}

The sampling technique which will be used in this research is, random sampling. In random sampling, each item or element of the population has an equal chance of being chosen at each draw. In this research all respondent of educational sector had an equal chance of being selected in order to fill the questionnaires. The total Sample size is 300. The Study participants has been taken from the education sector and observed through questionnaire and interview. For the data collection, questionnaire distributed in the education sector .Data is analyzed, through Amos software to calculate the statistical measure and then results were to be analyzed through multiple regressions 
to find the significance of data. Reliability of the variables are shown as, Manager Profile was (69\%), Business Education (80.7\%), Subordinate of ethics and social responsibility reliability $(83.8 \%)$.

\section{Results}

Responses were analyzed through structural equation model (AMOS).

\section{STRUCTURAL EQUATION MODEL (AMOS)}

Appendix A: See Figure 1.2

This model shows the relationship between variables. Structural equation model helps to measure impact of Independent variable on the subordinate of ethical and social responsibility, and on CSR. It further reveals the importance and role of each variable in the Manager Profile and business education model.

\section{Hypotheses Testing Based on Regression Weights}

\section{Appendix A: See Table 1.1}

Results of above hypotheses testing based on regression weights show relationship between constructs including Manager profile, business education, subordinate of ethics and corporate social responsibility, corporate social responsibility are shown in Table 1.1 .

Table 1.1 shows hypotheses testing based on regression weights; beta value is 0.294 between PRSR and MP and the relationship is evident from the analysis that if there is one degree change in Manager Profile there would be $29.4 \%$ increase in subordinate ethics of corporate social responsibility. Whereas beta value between BE and PRSR is 0.389 and 1 degree change in business education subordinate ethics of corporate social responsibility will increase $38.9 \%$. Beta value for subordinate ethics of corporate social responsibility and corporate social responsibility is -.354 and one degree change in subordinate ethics of corporate social responsibility increase corporate social responsibility to-35.4\%.Results show that beta value for MP and CSR is 0.166 and one degree change in Manager Profile will increase corporate social responsibility to $16.6 \%$.It is evident from result where beta value of BE and CSR is 0.314 and one degree change in Business education increase corporate social responsibility to $31.4 \%$

Table 1.1 show that relationships are statistically significant because $(\mathrm{P}<.05)$ so all hypotheses are accepted.

\section{DISCUSSION}

Impact of Manager Profile on Subordinate Ethics of Corporate Social Responsibility Hypothesis H1 is accepted that predicts manager profile positively enhance the relationship with subordinate ethics of corporate social responsibility. Result in table 1.1 shows positive relationship between manager profile and subordinate ethics of corporate social responsibility, Where $(\beta=.294)$ and $(\mathrm{P}<.05)$. It is evident from results that if manager work ethically then subordinate ethics of corporate social responsibility 
will increase.

\subsection{Impact of Business Education on Subordinate Ethics of Corporate Social Responsibility}

Hypothesis $\mathrm{H} 2$ predicts that business education positively enhance the relationship with subordinate ethics of corporate social responsibility. As discussed above that presence of business education increases benefits of subordinate ethics of corporate social responsibility. This study further reveals a positive relationship between business education and subordinate ethics of corporate social responsibility morale. It is evident from Table 1.1 shows $(\beta=.0389)$ and $(\mathrm{P}<.05)$. Results are consistent to previous studies that reveal positive relationship between business education and subordinate ethics of corporate social responsibility.

\subsection{Impact of Manager Profile on Corporate Social Responsibility}

Result predicts that manager profile positively enhance the relationship with the corporate social responsibility. Hambrick, 2007 describes that managers should have the ability to realize the direction how to act in socially responsible way in the organization. Result in table shows that manager profile has positive impact on corporate social responsibility because when managers work ethically then they fulfill the social responsibilities. It is evident from Table 1.1 shows that $(\beta=.166)$ and $(\mathrm{P}<.05)$. Results are consistent to previous studies that reveal positive relationship between manager profile and corporate social responsibility.

\subsection{Impact of Business Education and Corporate Social Responsibility}

Results predicts that business education positively enhance the corporate social responsibility. Edmondson \& Carroll (1999) describes that training is an important activity for the ethical social responsibility.in this article they take the corporate social responsibility as economic, ethical and legal responsibility. Angelidis \& Ibrahim in (2004) stated that researcher have done a lot of work on corporate social responsibility (CSR) but it in this study they focused on how business education and religion have impact on corporate social responsibility (CSR) In table 1.1 shows that $(\beta=.314)$ and $(\mathrm{P}<.05)$.Thus the results declare that business education and corporate social responsibility has positive impact.

\subsection{Impact of Subordinate Ethics of Corporate Social Responsibility on Corporate Social Responsibility}

Results predict that $(\beta=-.354)$ and $(\mathrm{P}<.05)$, According to the result it shows the negative relationship. Luis et al, (2010) also shows in their research that subordinate ethics of social responsibility and corporate social responsibility has negative relationship.

\section{CONCLUSION}

The overall main theme of this research is to make the manager's profile effective towards CSR so then only the CSR will have good impact on corporate community, current research also shows positive impact on CSR. Which tells us that manager profile can imply the power of ethics on the CSR with the help of Business education? Business Education is being highlighted in current research as a new contribution. If manager's 
gets proper education (training and corporate knowledge) for the organization which teaches corporate ethical behavior, it leads toward CSR but it couldn't be possible without a mediator. The subordinate of ethical and social responsibility plays a role of mediator among CSR, Business education and manager's profile. Therefore the collaborative effort of all the variables has further impact on CSR.

\section{FURTHER RESEARCH}

In previous studies focused on the top manager's perception regarding the role of ethics and social responsibility in the context of organizational effectiveness in such a way that organizations should deal with their managers through social responsibility which makes the managers convinced, though in an ethical way or having their own selfinterest (Handy,2002; Prahalad and Hammond,2002). The main purpose of adding this agency-stewardship approach is that it should be further explore by the research in future (Jose-Luis Godes-Di ez et al, 2011). With the help of previous studies, this current study encourages further research on the following variables which could have an effect on the future manager's performance regarding the role of ethics and social responsibility which would further have further impact on the companies and community. Those variables are cultural values and dimensions (Hofstede, 1983), religion (Worden, 2005), professional ethical standards (Valentine and Fleischman, 2008). Though among these variables business management education were the one variable which is researched in the current study, beside this variable the above mentioned variables are to be further bring in to account by the scholars whom will further bring impact on the CSR and managers' profile which will make the corporate environment healthier. This research recommends to further exploring the research study on CSR by adding new variables those are mentioned in future study. Though those variables would have different impact on CSR but would be beneficial for the corporate environment in near future.

\section{ACKNOWLEDGEMENT}

First of all with a profound gratitude, we are thankful to Almighty Allah forgiving us success, knowledge and understanding without which we would not been capable of completing this research paper.

We are also profoundly grateful to all our family members whose endurance and understanding have played a significant role in our success by sacrificing the important family time and supporting us all over the research work.

We are finally thankful to the editor, reviewers and IBT specially who provided us with the opportunity to publish our research paper in this esteemed journal.

\section{REFERENCES}

Angelidis, Ibrahim. (2004). An Exploratory Study of the Impact of Degree of Religiousness upon An Individual's Corporate Social Responsiveness Orientation. Journal of Business Ethics, 51, 119-128.

George Balabanis, Hugh C. Phillips, and Jonathan Lyall. (1998). Corporate Social 
Responsibility and Economic Performance in the Top British Companies.

European Business Review, 98(1), 25-44

Burke, Logsdon. (1996). How Corporate Social Responsibility Pays Off. Long Range Planning, 29(4), 495.

Carroll. (2000). Ethical Challenges for Business in the New Millennium. Business

Ethics Quarterly, 10(1).

James J. Chrisman, Jess H. Chua, \& Pramodita Sharma. (2003). Current Trends and

Future Directions in Family Business Management Studies. White Paper Series.

C Caldwell, R. Karri, P. Vollmar. (Apr., 2002). Principal Theory and Principle Theory:

Ethical Governance from the Follower's Perspective. Journal of Business Ethics.

66, 207-223.

C. Caldwell, R. Karri, T. Matula. (2005). Practicing What We Teach-Ethical

Considerations for Business Schools. Journal of Academic Ethics.

Carroll. (1999). Corporate Social Responsibility. Business and Society, 38, 268.

Christensen, et al (2007) "Ethics, CSR, and Sustainability Education in the Financial

Times Top 50 Global Business Schools" Journal of Business Ethics, Vol.73, pp.

347-368.

Davis et al. (1997) "The Distinctiveness of Agency Theory and Stewardship Theory"

The Academy of Management Review, Vol. 22, No. 3, pp. 611-613.

Davis et al, (1997) "Toward a Stewardship Theory of Management" The Academy of

Management Review, Vol. 22, No. 1, pp. 20-47.

Donaldson (Jul., 1990) "The Ethereal Hand: Organizational Economics and Management

Theory" The Academy of Management Review, Vol. 15, No. 3 pp. 369-381.

Edmondson.Cox, Carrol.B (1999). "Giving Back: An Examination of the Philanthropic

Motivations, Orientations and Activities of Large Black-Owned Businesses".

Journal of Business Ethics, 171-179.

GIACALONE.A, THOMPSON.R (2006). "Business Ethics and Social Responsibility

Education:Shifting the Worldview". Academy of Management Learning \&

Education, 266-277.

Guidice, Mero, (2007) “Governing joint ventures: tension among principals' dominant

logic on human motivation and behavior" J Manage Governance, Vol.11,

pp.261-283.

Hemingway, Maclagan (2004) “Managers' Personal Values as Drivers of Corporate

Social Responsibility" Journal of Business Ethics, Vol. 50, pp. 33-44.

Hernandez, (2008) "Promoting Stewardship Behavior in Organizations: A Leadership

Model" Journal of Business Ethics, Vol. 80, pp.121-128.

Henrique's, Sadorsky (Feb., 1999), “The Relationship between Environmental

Commitment and Managerial Perceptions of Stakeholder Importance" The

Academy of Management Journal, Vol. 42, No. 1 pp. 87-99.

Joyner, Payne (2002) "Evolution and Implementation: A Study of Values, Business

Ethics and Corporate Social Responsibility" Journal of Business Ethics, Vol.

41, pp297-311.

Jensen, "Value Maximization, Stakeholder Theory, and the Corporate Objective Function"

Business Ethics Quarterly, Vol. 12, No. 2, pp. 235-256

Kok et al (2001). "A Corporate Social Responsibility Audit within a Quality Management

Framework". Journal of Business Ethics, 285-297. 
Loe.Wel et al (2000). "Review of Empirica 1Studies Assessing Ethical Decision Making in Business" . Journal of Business Ethics, 185-204.

LeBlanc, N. (1997). "Searching for excellence in business education". International Journal of management, 72-79

Luthar.K, DiBattista.A,Gautschi ( 1997). "Perception of What the Ethical Climate is and What it Should be:The Role of Gender, Academic Status, and Ethical Education". Journal of Business Ethics, 205-217.

Matten, Moon, (2004) "Corporate Social Responsibility Education in Europe" Journal of Business Ethics, Vol. 54: pp323-337.

Marta etal. (2004) "Some important factors underlying ethical decisions of MiddleEastern marketers" International Marketing Review, Vol. 21 No. 1, pp. 53-67.

Mohr etal.(2001) "Do consumers expect companies to be socialy responsible" The journal of consumer affairs, Vol,35, No. 1

MOHR, Webb (2005) "The Effects of Corporate Social Responsibility and Price on Consumer Responses" The Journal of Consumer Affairs, Vol. 39, pp. 1.

PRESTON, BANNON (Dec 1997) "The corporate social -financial performance relationship"Lee E Preston; Douglas P O'Bannon Business and Society, Vol. 36 , No. 4.

Panapanaan, (2003) "Road mapping Corporate Social Responsibility in Finnish Companies" Journal of Business Ethics, Vol. 44, pp133-148.

Sleeper, et al (2006) "Scale and Study of Student Attitudes toward Business Education's Role in Addressing Social Issues" Journal of Business Ethics, Vol.68, pp. 381-391.

Sethi (Jan., 1979) "A Conceptual Framework for Environmental Analysis of Social Issues and Evaluation of Business Response Patterns" The Academy of Management Review, Vol. 4, No. 1, pp. 63-74

Singhapakdi etal,(2008) "Antecedents and Consequences of Perceived Importance of Ethics in Marketing Situations" journal of Business Ethics,Vol. 81, pp.887-904.

Singhapakdi et al (2001) "How important are ethics and social responsibility?" European Journal of Marketing, Vol. 35 No. 1/2, pp. 133-152.

Smith.L, O. ( 1997). "Gender-Related Differences in Ethical and Social Values of Business Students:Implications for Management". Journal of Business Ethics, $37-45$.

Trevino (Jul., 1986) "Ethical Decision Making in Organizations: A Person-Situation Integrationists Model" The Academy of Management Review, Vol. 11, No. 3, pp. 601-617

Wimbush.C et al (1997). "An Empirical Examination of the Relationship Between Ethical Climate and Ethical Behavior from Multiple Levels of Analysis". Journal of Business Ethics, 1705-1716. 


\section{APPENDIX A:}

FIG. 1.1

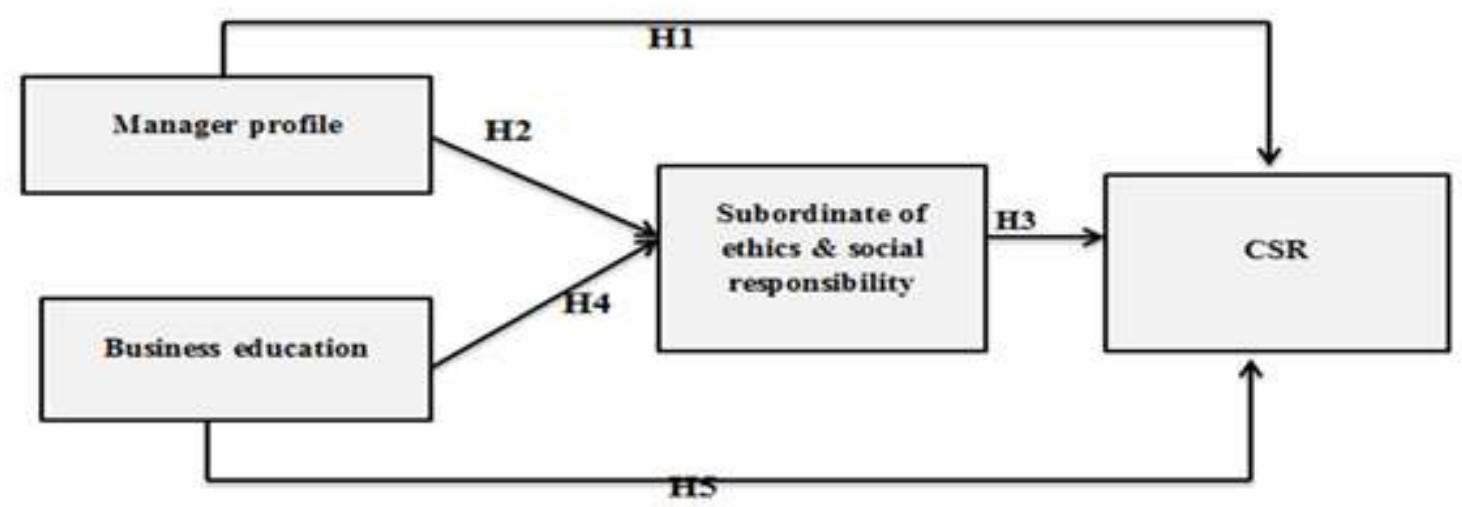

Fig. 1.2

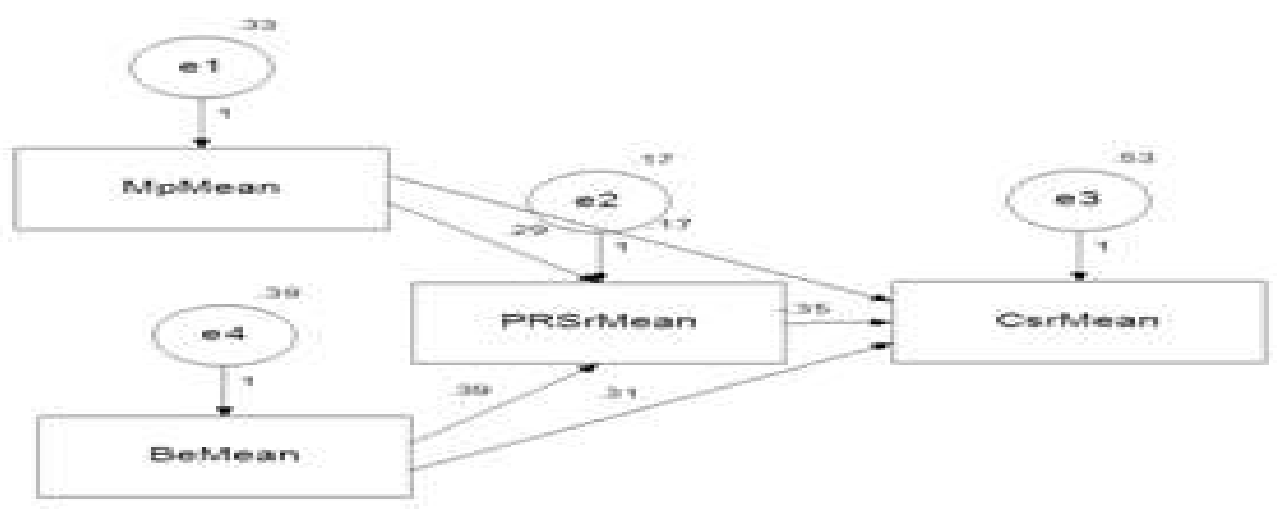

Figure 1.2 the result of Business Education and Manager Profile model

Mp Manager Profile PRSr Subordinate of Ethics and social Responsibility

Be Business Education Csr Corporate social responsibility 
TABLE 1.1

\begin{tabular}{|ll|c|c|c|c|}
\hline & & Estimate & S.E. & C.R. & P \\
\hline PRSr & $<---\mathrm{Mp}$ & .294 & .042 & 7.081 & 0.000 \\
$\mathrm{PRSr}$ & $<---\mathrm{Be}$ & .389 & .038 & 10.248 & 0.000 \\
$\mathrm{Csr}$ & $<---\mathrm{PRSr}$ & -.354 & .103 & -3.450 & 0.000 \\
$\mathrm{Csr}$ & $<--\mathrm{Mp}$ & .166 & .080 & 2.087 & 0.037 \\
$\mathrm{Csr}$ & $<--\mathrm{Be}$ & .314 & .078 & 4.025 & 0.000 \\
\hline
\end{tabular}

